\title{
Physiological and ionic changes in dwarf coconut seedlings irrigated with saline water
}

\author{
Breno L. de C. Lima ${ }^{1}$, Claudivan F. de Lacerda ${ }^{2}$, Miguel Ferreira Neto ${ }^{3}$, \\ Jorge F. da S. Ferreira ${ }^{4}$, Antonio M. E. Bezerra ${ }^{5}$ \& Elton C. Marques ${ }^{3}$ \\ ${ }^{1}$ Universidade Federal Rural de Pernambuco/Departamento de Engenharia Agrícola/Programa de Pós-Graduação em Engenharia Agrícola. Recife, PE. \\ E-mail: breno.lclima@uol.com.br (Corresponding author) \\ ${ }^{2}$ Universidade Federal do Ceará/Centro de Ciências Agrárias/Departamento de Engenharia Agrícola. Fortaleza, CE. E-mail: cfeitosa@ufc.br \\ ${ }^{3}$ Universidade Federal Rural do Semi-Árido/Departamento de Ciências Ambientais e Tecnológicas/Programa de Pós-Graduação em Manejo de Solo e \\ Água. Mossoró, RN. E-mail: miguel@ufersa.edu.br; eltoncmarques@gmail.com \\ ${ }^{4}$ United States Department of Agriculture/Agricultural Research Service/U. S. Salinity Laboratory. Riverside, CA. E-mail: jorge.ferreira@ars.usda.gov \\ ${ }^{5}$ Universidade Federal do Ceará/Centro de Ciências Agrárias/Departamento de Fitotecnia. Fortaleza, CE. E-mail: esmeraldobezerra@yahoo.com.br
}

\section{Key words:}

Cocos nucifera L.

salt tolerance

organic solutes

\begin{abstract}
A B S T R A C T
Salt-tolerant plants are important to cope with salinity and/or sodicity problems in semiarid regions. The dwarf coconut palm (Cocos nucifera L.) has emerged as a salt-tolerant crop once established. However, little is known about the mechanisms that contribute to the survival of coconut seedlings under salinity stress. This study aimed to evaluate the effect of saline water on morpho-physiological and biochemical responses of dwarf coconut seedlings. Treatments were composed of five levels of water salinity, expressed by its electrical conductivity (ECw), as follows: 0.9 (control); 5.2; 10.1; 15.3 and $19.3 \mathrm{dS} \mathrm{m}^{-1}$ in a completely randomized design with four replications. The high levels of organic solutes (carbohydrates and soluble amino-N) and $\mathrm{Na}^{+}$in roots, that contribute to the low values of $\mathrm{Na}^{+} / \mathrm{K}^{+}$ratio in the leaves, suggest that roots play an important role in the mechanism of salt tolerance of coconut seedlings. The use of brackish water with ECw of $5.2 \mathrm{dS} \mathrm{m}^{-1}$ allows seedling production, with no loss of quality. Based on total dry matter accumulation, seedlings were classified as moderately tolerant to the salinity of $10.1 \mathrm{dS} \mathrm{m}^{-1}$.
\end{abstract}

\section{Palavras-chave: \\ Cocos nucifera L. tolerância à salinidade solutos orgânicos}

\section{Alterações fisiológicas e iônicas em mudas de coqueiro anão irrigado com águas salinas}

\begin{abstract}
R E S U M O
A utilização de plantas tolerantes ao estresse salino é necessária para remediar o problema da salinidade e/ou sodicidade em regiões semiáridas. Deste modo, o coqueiro anão (Cocos nucifera L.) vem se destacando como uma cultura tolerante ao estresse salino, porém pouco se sabe sobre os mecanismos que contribuem para a tolerância dessa espécie. Neste contexto, objetivou-se com este trabalho avaliar as respostas fisiológicas e iônicas de mudas de coqueiro anão em função do estresse salino. Os tratamentos compreenderam cinco níveis de salinidade da água de irrigação - CEa: 0,9 (tratamento controle); 5,2; 10,1; 15,3 e 19,3

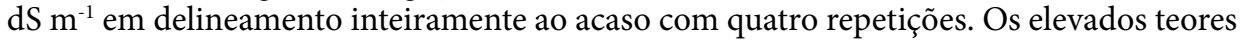
de solutos orgânicos (carboidratos e $\mathrm{N}$-aminossolúveis) e a retenção de $\mathrm{Na}^{+}$nas raízes, o que favoreceu a manutenção de baixos valores da relação $\mathrm{Na}^{+} / \mathrm{K}^{+}$nas folhas, indicam que o sistema radicular desempenha papel importante no mecanismo de tolerância das mudas de coqueiro à salinidade. O uso de água salobra com $\mathrm{CEa}$ de $5,2 \mathrm{dS} \mathrm{m}^{-1}$ permite a produção de mudas, sem perda de qualidade na fase de viveiro. As mudas foram classificadas como moderadamente tolerantes à salinidade de $10,1 \mathrm{dS} \mathrm{m}^{-1}$ baseado na massa seca total da planta.
\end{abstract}




\section{INTRODUCTION}

The major aim of coconut cultivation in Brazil is the production of coconut water, which has expanded in the last years to meet the demand for the consumption of products of natural hydration (Costa et al., 2015). The country is the main global producer and the states of Bahia, Ceará and Sergipe are the largest national producers. The 'Anão Verde' variety is favored due to its early production, good yield and quality of the water, in addition to its good adaptation to tropical climates, water resources and soils (Holanda et al., 2007).

The use of brackish waters, associated with strategies such as the cultivation of salt-tolerant plants to reduce the effects of the salts on crop yield, can contribute to the socioeconomic sustainability of agricultural systems (Lacerda et al., 2011; Neves et al., 2015).

The viability of the use of brackish waters in coconut cultivation has been demonstrated (Marinho et al., 2005a;b), but little is known about mechanisms which contribute to the adaptation of this species to saline conditions. Thus, studies on the production of seedlings with saline waters, are of great importance to ascertain the future establishment of dwarf coconut plantations under saline environment.

The reduction in photosynthesis is one of the effects of salts on plants (Souza et al., 2011), which decreases as a consequence of stomatal closure and/or alterations in photochemical and biochemical reactions of the photosynthetic process (Praxedes et al., 2010). Another effect is the accumulation of $\mathrm{Na}^{+}$ions in plant tissues, which can inhibit growth and cause morphophysiological disorders (Parida \& Jha, 2013). According to these authors, plant develop mechanisms to cope with the salt stress, which include osmotic adjustment, i.e., the reduction of the osmotic potential associated with the accumulation of compatible solutes (such as proline and sugars) of low molecular weight in the cytoplasm and compartmentalization of potentially toxic ions in the vacuoles, maintaining cell turgor.

Therefore, this study aimed to evaluate the effects of irrigation with brackish water on the morpho-physiological and biochemical responses in dwarf coconut seedlings.

\section{Material AND Methods}

The experiment was carried out from December 2012 to April 2013, in a greenhouse at the Center of Teaching and Research of Urban Agriculture - NEPAU/CCA/UFC, Fortaleza, Ceará, Brazil. The local geographic coordinates are $3^{\circ} 44^{\prime} 16^{\prime \prime}$ $\mathrm{S}, 38^{\circ} 34^{\prime} 22^{\prime \prime} \mathrm{W}$ and mean altitude of $19 \mathrm{~m}$ above sea level.

The treatments consisted of five levels of irrigation water salinity, which were expressed by the electrical conductivity of the water (ECw): 0.9 (control treatment), 5.2, 10.1, 15.3 and $19.3 \mathrm{dS} \mathrm{m}^{-1}$. The adopted experimental design was completely randomized, with four replications, and each plot consisted of four plants, one plant per pot, totaling 80 pots.

This study used seedlings of dwarf coconut, cv. 'Anão Verde', with age of four months, having on average 2.4 leaves per plant and height of $56.0 \mathrm{~cm}$. Initially, seedlings underwent the removal of both epicarp and mesocarp from the coconut seed, of greater protuberance, to increase hydration. After this preparation, the seedlings were placed in a vertical position, according to Wuidart \& Lamothe (1981), in flexible pots with capacity for $25 \mathrm{~L}$, perforated at the bottom. The pots were filled with a $3.0 \mathrm{~cm}$ layer of crushed stone No. 1, involved in geotextile draining blanket (Bidim, OP-20) on its surface to facilitate water drainage.

The substrate consisted of the mixture of 'arisco' (fine sandsized particles used in constructions) and organic compost, at the proportion of 2:1 (volume of 'arisco': volume of organic compost), which was homogenized and then sieved through a $6.0-\mathrm{mm}$ mesh. The physico-chemical characteristics of the substrate, analyzed according to EMBRAPA (1997), were: coarse sand $=517 \mathrm{~g} \mathrm{~kg}^{-1}$, fine sand $=312 \mathrm{~g} \mathrm{~kg}^{-1}$, silt $=108 \mathrm{~g} \mathrm{~kg}^{-1}$, clay $=63 \mathrm{~g} \mathrm{~kg}^{-1}$, natural clay $=30 \mathrm{~g} \mathrm{~kg}^{-1}$, textural class $=$ loamy sand, soil bulk density $=1.31 \mathrm{~kg} \mathrm{dm}^{-3}$, soil particle density $=$

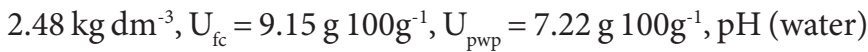
$=6.8, \mathrm{Ca}^{2+}=5.70 \mathrm{cmol}_{\mathrm{c}} \mathrm{kg}^{-1}, \mathrm{Mg}^{2+}=4.60 \mathrm{cmol}_{\mathrm{c}} \mathrm{kg}^{-1}, \mathrm{Na}^{+}=0.71$ $\mathrm{cmol}_{\mathrm{c}} \mathrm{kg}^{-1}, \mathrm{~K}^{+}=4.60 \mathrm{cmol}_{\mathrm{c}} \mathrm{kg}^{-1}, \mathrm{H}^{+}+\mathrm{Al}^{3+}=1.98 \mathrm{cmol}_{\mathrm{c}} \mathrm{kg}^{-1}, \mathrm{~S}$ $=15.6 \mathrm{cmol}_{\mathrm{c}} \mathrm{kg}^{-1}, \mathrm{~T}=17.6 \mathrm{cmol}_{\mathrm{c}} \mathrm{kg}^{-1}, \mathrm{~V}=89 \%, \mathrm{~m}=5 \%, \mathrm{ESP}=$ $4 \%, \mathrm{C}=16.00 \mathrm{~g} \mathrm{~kg}^{-1}, \mathrm{~N}=1.67 \mathrm{~g} \mathrm{~kg}^{-1}, \mathrm{OM}=27.50 \mathrm{~g} \mathrm{~kg}^{-1}$.

The waters used in irrigation were obtained through the dissolution of sodium chloride $(\mathrm{NaCl})$, calcium chloride $\left(\mathrm{CaCl}_{2} \cdot 2 \mathrm{H}_{2} \mathrm{O}\right)$ and magnesium chloride $\left(\mathrm{MgCl}_{2} \cdot 6 \mathrm{H}_{2} \mathrm{O}\right)$ in the water of lower electrical conductivity $\left(\mathrm{ECw}=0.9 \mathrm{dS} \mathrm{m}^{-1}\right)$ from the urban supply system, in equivalent proportion of 7:2:1 of $\mathrm{Na}: \mathrm{Ca}: \mathrm{Mg}$, respectively. Irrigation was manually performed using a graduated container, from December 2012 until 120 days after the treatments (DAT), with the respective waters of each treatment applied late afternoon, when a water depth of $7 \mathrm{~mm} \mathrm{~d}^{-1}$ was then adopted according to the recommendations of the alternative system of production of coconut seedlings (Fontes et al., 2002). Irrigations were performed daily and stopped when drainage was noticeable from the pots, and the water depths were differentiated as the seedlings grew, adopting a leaching fraction (LF) of 0.20 along the experiment, to adjust the applied water volume to the respective treatments, based on the relationship of ECse $=1.5 \mathrm{ECw}$ (Ayers \& Westcot, 1999). Plants were fertilized following the recommendations of Fontes et al. (1997), 30 days after planting the seedlings in the pots, with top-dressing applications, until the $4^{\text {th }}$ month, in monthly portions of $10 \mathrm{~g}$ of single superphosphate, $3.3 \mathrm{~g}$ of urea and $1.6 \mathrm{~g}$ of potassium chloride per plant.

Net assimilation rates $\left(\mathrm{A}, \mu \mathrm{mol} \mathrm{CO} \mathrm{C}^{-2} \mathrm{~s}^{-1}\right)$ were determined using an infrared gas analyzer (IRGA - LI-COR, model LI$6400 \mathrm{XT}$ ) from 8 to 9 a.m., at 40, 80 and 120 DAT, using leaf $\mathrm{n}^{\circ} 2$ as standard for evaluations, considering the 'arrow' leaf (youngest leaf produced) as the leaf No. 0, counting from the youngest to the oldest one, until the No. 2 . The readings were obtained using an artificial source of photosynthetically active radiation of $1500 \mu \mathrm{mol} \mathrm{m} \mathrm{m}^{-2} \mathrm{~s}^{-1}$, with ambient temperature and $\mathrm{CO}_{2}$ concentration. These data were used to obtain a mean of the net $\mathrm{CO}_{2}$ assimilation rate $\left(\mathrm{A}_{\text {mean }}\right)$ of the three evaluated periods for each treatment.

At the end of the experiment (120 DAT), two plants were collected per plot in each treatment to determine root dry matter (RDM), shoot dry matter (SDM) and total dry matter 
$(\mathrm{TDM}=\mathrm{RDM}+\mathrm{SDM})$. For dry matter determination, the organs were dried in a forced-air oven at $65^{\circ} \mathrm{C}( \pm 1)$ until constant weight.

After drying, the samples of shoots (petiole + rachis + leaflets) and roots were finely ground in a Wiley-type mill (model MA 340, Marconi, BR) to determine the contents of $\mathrm{Na}^{+}, \mathrm{K}^{+}$and $\mathrm{Cl}^{-}$, according to Malavolta et al. (1997).

The extracts for the determination of organic solutes were obtained by homogenizing $100 \mathrm{mg}$ of powdered of lyophilized leaflets and roots with $5.0 \mathrm{~mL}$ of deionized water, according to Oliveira et al. (2013). The contents of proline were determined following the method of Bates et al. (1973), the contents of soluble amino-N according to Yemm \& Cocking (1955) and the contents of carbohydrates through the method of Dubois et al. (1956).

Salt tolerance was determined based on the methodology described by Fageria et al. (2010), using data of dry biomass production and mean rates of net $\mathrm{CO}_{2}$ assimilation $\left(\mathrm{A}_{\text {mean }}\right)$, considering its percent reductions under different saline treatments in relation to the control: tolerant (reduction of $0-20 \%)$, moderately tolerant (20-40\%), moderately sensitive (40-60\%) and sensitive (reduction above 60\%).

The obtained data were subjected to analysis of variance at the 0.05 probability level. The effects of salinity on the response variables (y), when significant, were subjected to regression analysis and mathematically fitted to polynomial models of higher significance degree, using a mathematical model that most reflected the studied biological phenomenon.

\section{Results AND Discussion}

For the water salinity levels of 5.2 and $10.1 \mathrm{dS} \mathrm{m}^{-1}$, the coconut cv. "Anão Verde" was tolerant or moderately tolerant to salinity, respectively, considering the relative reductions in biomass production and mean net $\mathrm{CO}_{2}$ assimilation rate, according to the methodology described by Fageria et al. (2010). Except for root dry matter, SDM, TDM and $A_{\text {mean }}$ indicated moderate susceptibility or susceptibility to the salinity levels of 15.3 and $19.3 \mathrm{dS} \mathrm{m}^{-1}$, respectively (Table 1). In general, there was a similar reduction for shoot growth and mean photosynthetic rates along the experiment. On the other hand, coconut RDM showed a lower percent reduction than SDM, even at the highest water salinity levels, indicating a higher degree of tolerance to salinity in comparison to SDM.

After 120 days of irrigation with brackish water, there was an ionic competition between sodium and potassium, with

Table 1. Percent reduction of biomass production, mean photosynthetic rate, and salt tolerance classification for coconut seedlings irrigated with brackish waters

\begin{tabular}{ccccc}
\hline \multirow{2}{*}{ Variables } & \multicolumn{4}{c}{ Percent reduction (\%) } \\
\cline { 2 - 5 } & $\mathbf{5 . 2}$ & \multicolumn{4}{c}{$\mathbf{1 0 . 1}$} & $\mathbf{1 5 . 3}$ & $\mathbf{1 9 . 3}$ \\
\cline { 2 - 5 } RDM & $12.27^{\mathrm{T}}$ & $15.88^{\mathrm{T}}$ & $21.56^{\mathrm{MT}}$ & $29.74^{\mathrm{MT}}$ \\
SDM & $15.45^{\mathrm{T}}$ & $33.02^{\mathrm{MT}}$ & $51.75^{\mathrm{MS}}$ & $66.12^{\mathrm{S}}$ \\
TDM & $14.69^{\mathrm{T}}$ & $31.43^{\mathrm{MT}}$ & $49.19^{\mathrm{MS}}$ & $62.85^{\mathrm{S}}$ \\
A $_{\text {mean }}$ & $20.57^{\mathrm{MT}}$ & $39.49^{\mathrm{MT}}$ & $54.32^{\mathrm{MS}}$ & $62.04^{\mathrm{S}}$ \\
\hline
\end{tabular}

${ }^{\mathrm{T}}$, MT, MS ${ }^{\text {Mnd }}{ }^{\mathrm{S}}$ - Tolerant, moderately tolerant, moderately sensitive and sensitive, respectively; RDM - Root dry matter; SDM - Shoot dry matter; TDM - Total dry matter; $A_{\text {mean }}$ - Mean net $\mathrm{CO}_{2}$ assimilation rate increasing linear response for the contents of $\mathrm{Na}^{+}$in the roots (Figure 1A), while an antagonistic response was observed for $\mathrm{K}^{+}$(Figure 1B). In the shoots, the increase in irrigation water salinity did not cause significant changes in the contents of $\mathrm{Na}^{+}$ and/or $\mathrm{K}^{+}$(Figures 1A and 1B), resulting in the maintenance of low values of the $\mathrm{Na} / \mathrm{K}$ ratio in this plant organ. On the other hand, $\mathrm{Cl}^{-}$(Figure 1C) increased with salinity in both studied organs; roots showed a linear increase, while shoots showed a quadratic increase.

The greatest accumulation of potentially toxic ions (particularly $\mathrm{Na}^{+}$and $\mathrm{Cl}^{-}$) in the leaf tissues of glycophytes is correlated with the sensitivity to salt stress (Trindade et al., 2006). In the present study, however, there was a high
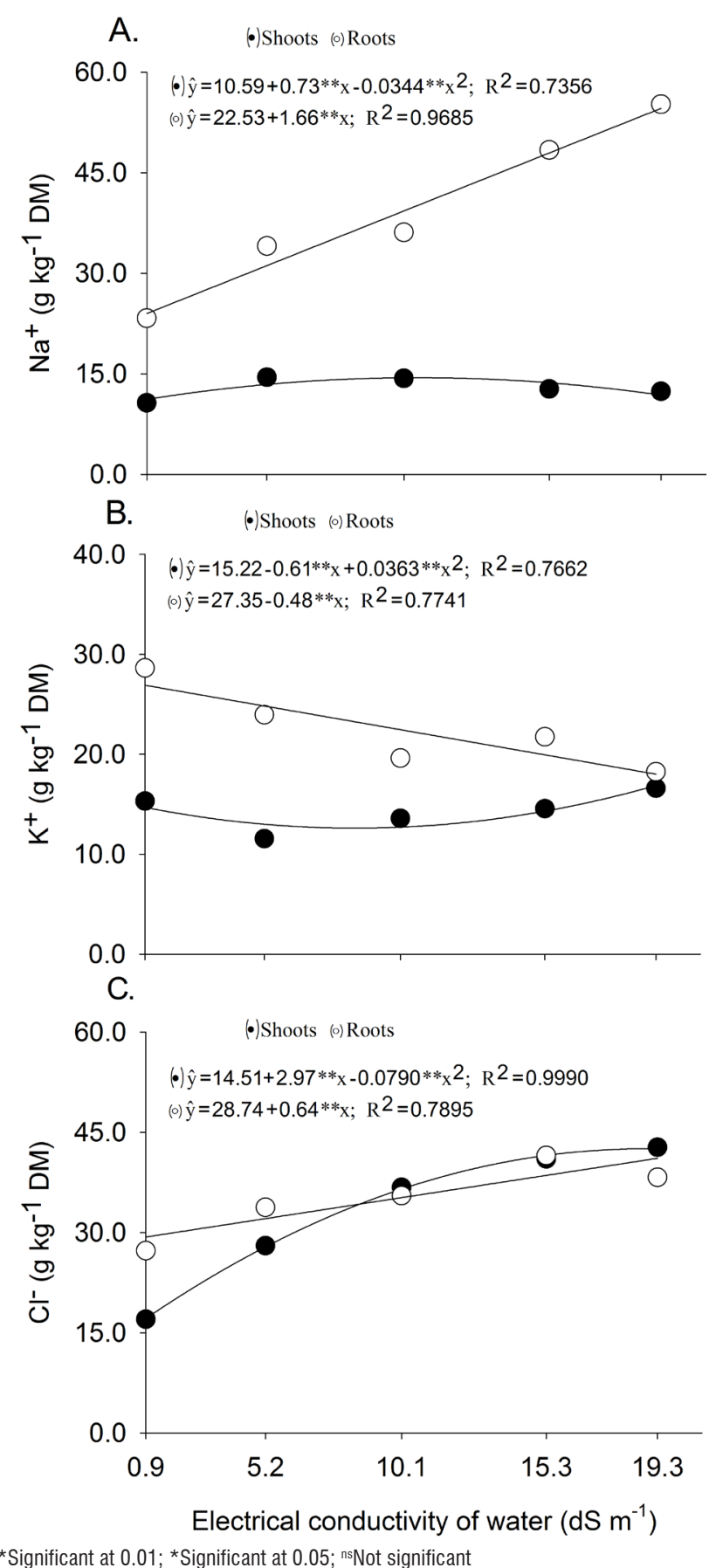

Figure 1. Contents of $\mathrm{Na}^{+}(\mathrm{A}), \mathrm{K}^{+}(\mathrm{B})$ and $\mathrm{Cl}^{-}(\mathrm{C})$ in dwarf coconut seedlings, cv. 'Anão Verde', at 120 days after treatment as a function of irrigation water salinity 
accumulation of $\mathrm{Na}^{+}$in the roots, while the content in the shoots remained low, even at the highest levels of salinity. This mechanism of retention, evidenced for $\mathrm{Na}^{+}$, may be important in the tolerance to salinity (Aquino et al., 2007), mainly considering that in the present study there were no visual effects of $\mathrm{Na}^{+}$toxicity in leaves of dwarf coconut during the studied period, even when irrigation water salinity reached EC of $19.3 \mathrm{dS} \mathrm{m}^{-1}$.

The higher $\mathrm{Na}^{+}$content in the roots also contributed to the maintenance of lower values of $\mathrm{Na}^{+} / \mathrm{K}^{+}$ratio in the shoots, a very relevant characteristic for the tolerance to salinity of glycophytes (Lacerda et al., 2003; Aquino et al., 2007). It is important to point out that, although $\mathrm{Na}^{+}$can substitute for $\mathrm{K}^{+}$in the process of osmotic adjustment, it does not in specific functions of $\mathrm{K}^{+}$in plant metabolism. Thus, the maintenance of lower $\mathrm{Na}^{+} / \mathrm{K}^{+}$ratios in the leaf tissues (Taiz \& Zeiger, 2013), as observed in the present study, reduces the impacts of salt stress on the metabolism and production of photoassimilates (Aquino et al., 2007).

Marinho (2002), studying the effect of irrigation with saline water on dwarf coconut cultivation, proposed that there was a stabilization of $\mathrm{Na}^{+}$contents in shoots from the level of $5.0 \mathrm{dS}$ $\mathrm{m}^{-1}$ on, with no proportional increase in the contents of this ion as irrigation water salinity increased. Hence, these authors suggested the existence of a limit in $\mathrm{Na}^{+}$accumulation in plant shoots with the increase in irrigation water salinity.

Ferreira Neto et al. (2007) evaluated the effects of irrigation with saline water during the initial stage of production (3.5 years) of dwarf coconut and observed contrary results regarding the accumulation of $\mathrm{Na}^{+}$and $\mathrm{K}^{+}$, in relation to those found in the present study. These authors reported increase in the leaf content of $\mathrm{Na}^{+}$and reduction in the contents of $\mathrm{K}^{+}$, suggesting ionic competition between these ions in the process of root absorption and/or differences in the retention rates in the process of transport to the shoots. These differences may be related to the time of exposure to the stress, plant age and types of salts used in the irrigation water, and the present study used a mixture of salts of $\mathrm{Na}, \mathrm{Ca}$ and $\mathrm{Mg}$. Also, in the study of Ferreira Neto et al. (2007) the only salt used was $\mathrm{NaCl}$.

Since there is not an adequate range for optimal and critical values of leaf $\mathrm{Cl}^{-}$contents for coconut in nursery stage and considering the values described by Uexkull (1972) for coconut in production stage ( $4.5 \mathrm{~g} \mathrm{~kg}^{-1}$ in the leaves), $\mathrm{Cl}^{-}$content in the leaves at the highest level was nine times higher than the optimal value described by Uexkull (1972). In spite of that, there were no symptoms of $\mathrm{Cl}^{-}$toxicity, which can be associated with the functions of this element in coconut plants. It is important to emphasize that the contents of ions in the shoots, in the present study, represent the mean of the contents in the leaf blades, petioles and rachis, which suggests the possibility of compartmentalization in these tissues, as observed in cowpea and sorghum (Trindade et al., 2006; Aquino et al., 2007).

The contents of proline (Figure 2A), carbohydrates (Figure 2B) and soluble amino-N (Figure 2C) significantly increased in the roots by the increment in the electrical conductivity of the irrigation water, which was not observed in the leaflets. $(\bullet)$ Leaflets $(\circ)$ Roots
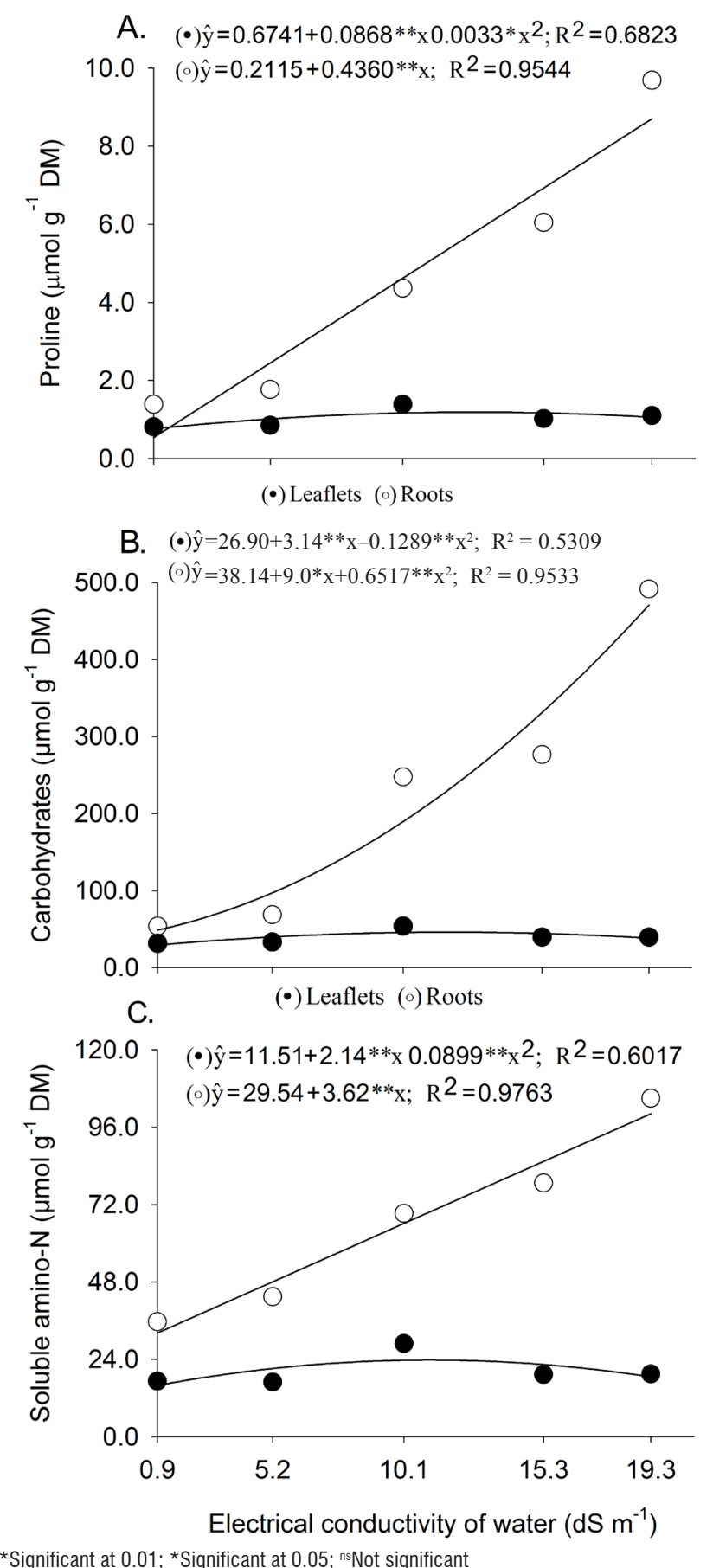

Figure 2. Contents of proline (A), soluble carbohydrates (B) and soluble amino-N (C) in dwarf coconut seedlings, cv. 'Anão Verde', at 120 dats after treatment as a function of irrigation water salinity

The increase in the contents of soluble amino-N, carbohydrates and proline in the roots of coconut seedlings, also observed in other studies (Lacerda et al., 2003; Trindade et al., 2006; Mendes et al., 2011; Cunha et al., 2013), suggests that these solutes may be contributing to the osmotic adjustment of the root cells, decreasing the osmotic potential of subcellular compartments, or may be associated with other functions of protection against the damages caused by salt stress. According to Praxedes et al. (2009) in the cowpea crop (Vigna unguiculata (L.) Walp), the increase in the accumulation of proline is a mechanism of protection against excess of salts. However, for 
Lacerda et al. (2003), the accumulation of proline seems to be a reaction to the damages caused by the salt stress and not a response of the plant associated with the tolerance to salt stress.

The similarity of the responses observed for the concentrations of $\mathrm{Na}^{+}$and $\mathrm{Cl}^{-}$, and of organic solutes, in both shoots and roots of coconut, suggests that the increase in the accumulation of organic solutes in the leaflets is associated with the increments in the contents of potentially toxic elements, corroborating the results of Trindade et al. (2006) for sorghum and cowpea. However, the increase in the contents of these solutes in roots, especially soluble amino- $\mathrm{N}$ and carbohydrates, and the retention of $\mathrm{Na}^{+}$in roots with increased water salinity, when compared to the same parameters in leaflets, suggest that the root system plays an important role in the tolerance to salt stress in coconut seedlings.

\section{Conclusions}

1. Dwarf coconut in the nursery stage is tolerant to irrigation water salinity of $5.2 \mathrm{dS} \mathrm{m}^{-1}$ and moderately tolerant to salinity of $10.1 \mathrm{dS} \mathrm{m}^{-1}$.

2. The high contents of organic solutes and the retention of $\mathrm{Na}^{+}$in the roots, which favor the maintenance of low values of $\mathrm{Na}^{+} / \mathrm{K}^{+}$ratio in the leaves, indicate that the root system plays a fundamental role in the mechanism of tolerance of coconut seedlings to salinity.

3. The results indicate the viability of using brackish water with ECw of up to $5.2 \mathrm{dS} \mathrm{m}^{-1}$ in the production of dwarf coconut seedlings, without loss of quality and standard of the seedlings at the nursery stage.

\section{Literature Cited}

Aquino, A. J. S.; Lacerda, C. F. de; Bezerra, M. A.; Gomes Filho, E; Costa, R. N. T. Crescimento, partição de matéria seca e retenção de $\mathrm{Na}^{+}, \mathrm{K}^{+}$e $\mathrm{Cl}^{-}$em dois genótipos de sorgo irrigados com águas salinas. Revista Brasileira de Ciência do Solo, v.31, p.961-971, 2007. https://doi.org/10.1590/S0100-06832007000500013

Ayers, R. S.; Westcot. D. W. A qualidade de água na agricultura. 2.ed. Campina Grande: UFPB, 1999. 159p. Estudos FAO: Irrigação e Drenagem, 29 revisado 1.

Bates, L. S.; Waldren, R. P.; Teare, I. D. Rapid determination of free proline for water-stress studies. Plant and Soil, v.39, p.205-207, 1973. https://doi.org/10.1007/BF00018060

Costa, H. B.; Souza, L. M.; Soprani, L. C.; Oliveira, B. G.; Ogawa, E. M.; Korres, A. M. N.; Ventura, J. A.; Romão, W. Monitoring the physico-chemical degradation of coconut water using ESI-FTICR MS. Food Chemistry, v.174, p.139-146, 2015. https://doi. org/10.1016/j.foodchem.2014.10.154

Cunha, P. C.; Mendes, B. S. S.; Oliveira Filho, R. A.; Camara, T. R.; Willadino, L. G. Crescimento, síntese de solutos orgânicos e equilíbrio iônico de plântulas de pinhão-manso sob estresse salino. Revista Caatinga, v.26, p.46-52, 2013.

Dubois, M.; Gilles, K. A.; Hamilton, J. K.; Rebers, P. A.; Smith, F. Colorimetric method for determination of sugars and related substances. Analytical Chemistry, v.28, p.350-356, 1956. https:// doi.org/10.1021/ac60111a017
EMBRAPA - Empresa Brasileira de Pesquisa Agropecuária. Manual de métodos de análise de solo. Rio de Janeiro: Embrapa Solos, 1997. 212p.

Fageria, N. K.; Soares Filho, W. S.; Gheyi, H. R. Melhoramento genético vegetal e seleção de cultivares tolerantes à salinidade, In: Gheyi, H. R.; Lacerda, C. F. de; Dias, N. da S. Manejo da salinidade na agricultura: Estudos básicos e aplicados. Fortaleza: INCTSal, 2010. Cap.13, p.205-218.

Ferreira Neto, M.; Gheyi, H. R.; Fernandes, P. D.; Holanda, J. S.; Blanco, F. F. Emissão foliar, relações iônicas e produção do coqueiro irrigado com água salina. Ciência Rural, v.37, p.1675-1681, 2007. https://doi.org/10.1590/S0103-84782007000600026

Fontes, H. R.; Cintra, F. L. D.; Carvalho Filho, O. M. Implantação e manejo da cultura do coqueiro. In: Ferreira, J. M. S.; Warwick, D. R. N.; Siqueira, L. A. (ed.) A cultura do coqueiro no Brasil. Aracaju: Embrapa Tabuleiros Costeiros, 1997. Cap.5, p.99-71.

Fontes, H. R.; Ferreira, J. M. S.; Siqueira, L. A. Sistema de produção para a cultura do coqueiro. Aracaju: Embrapa Tabuleiros Costeiros, 2002. 65p.

Holanda, J. S.; Ferreira Neto, M.; Silva, R. A.; Chagas, M. C. M.; Sobral, L. F.; Gheyi, H. R. Tecnologias para produção intensiva de coco anão verde. Natal: EMPARN, 2007. 40p.

Lacerda, C. F. de; Cambraia, J.; Oliva, M. A.; Ruiz, H. A.; Prisco, J. T. Solute accumulation and distribution during shoot and leaf development in two sorghum genotypes under salt stress. Environmental and Experimental Botany, v.49, p.107-120, 2003. https://doi.org/10.1016/S0098-8472(02)00064-3

Lacerda, C. F. de; Silva, F. B.; Neves, A. L. R.; Silva, F. L. B.; Gheyi, H. R.; Ness, R. L. L.; Gome-Filho, E. Influence of plant spacing and irrigation water quality on a cowpea-maize cropping system. International Research Journal of Agricultural Science and Soil Science, v.1, p.163-171, 2011.

Malavolta, E.; Vitti, G. C.; Oliveira, S. A. Avaliação do estado nutricional de plantas: Princípios e aplicações. Piracicaba: Potafos, 1997. 308p.

Marinho, F. J. L. Germinação, crescimento e desenvolvimento do coqueiro Anão Verde sob estresse salino. Campina Grande: UFCG, 2002. 196p. Tese Doutorado

Marinho, F. J. L.; Ferreira Neto, M.; Gheyi, H. R.; Fernandes, P. D.; Viana, S. B. A. Uso de água salina na irrigação do coqueiro (Cocus nucifera L.). Revista Brasileira de Engenharia Agrícola e Ambiental, v.9 (suplemento), p.359-364, 2005a.

Marinho, F. J. L.; Gheyi, H. R.; Fernandes, P. D. Germinação e formação de mudas de coqueiro irrigadas com águas salinas. Revista Brasileira de Engenharia Agrícola e Ambiental, v.9, p.334340, 2005b. https://doi.org/10.1590/S1415-43662005000300007

Mendes, B. S. S.; Willadino, L. G.; Cunha, P. C.; Oliveira Filho, R. A.; Camara, T. R. Mecanismo fisiológicos e bioquímicos do abacaxi ornamental sob estresse salino. Revista Caatinga, v.24, p.71-77, 2011.

Neves, A. L. R.; Lacerda, C. F. de; Sousa, C. H. C.; Silva, F. L. B.; Gheyi, H. R.; Ferreira, F. J.; Andrade Filho, F. L. Growth and yield of cowpea/sunflower crop rotation under different irrigation management strategies with saline water. Ciência Rural, v.45, p.814-820, 2015.

Oliveira, V. P.; Marques, E. C.; Lacerda, C. F. de; Prisco, J. T.; Gomes Filho, E. Physiological and biochemical characteristics of Sorghum bicolor and Sorghum sudanense subjected to salt stress in two stages of development. African Journal of Agricultural Research, v.8, p.660-670, 2013. 
Parida, A. K.; Jha, B. Inductive responses of some organic metabolites for osmotic homeostasis in peanut (Arachis hypogaea L.) seedlings during salt stress. Acta Physiologiae Plantarum, v.35, p.2821-2832, 2013. https://doi.org/10.1007/s11738-013-1315-9

Praxedes, S. C.; Ferreira, T. M.; Gomes-Filho, E. Acúmulo de prolina e aminoácidos em cultivares de feijão caupi com tolerância diferencial à salinidade. Revista Caatinga, v.22, p.211-214, 2009.

Praxedes, S. C.; Lacerda, C. F. de; DaMatta, F. M.; Prisco, J. T.; GomesFilho, E. Salt tolerance is associated with differences in ion accumulation, biomass allocation and photosynthesis in cowpea cultivars. Journal of Agronomy and Crop Science, v.196, p.193204, 2010. https://doi.org/10.1111/j.1439-037X.2009.00412.x

Souza, R. P.; Machado, E. C.; Silveira, J. A. G.; Ribeiro, R. V. Fotossíntese e acúmulo de solutos em feijoeiro caupi submetido à salinidade. Pesquisa Agropecuária Brasileira, v.46, p.586-592, 2011. https://doi.org/10.1590/S0100-204X2011000600003
Taiz, L.; Zeiger, E. Fisiologia vegetal. 5.ed. Porto Alegre: Artmed, 2013. 918p.

Trindade, A. R.; Lacerda, C. F. de; Gomes Filho, E.; Prisco, J. T.; Bezerra, M. A. Influência do acúmulo e distribuição de íons sobre a aclimatação de plantas de sorgo e feijão-de-corda, ao estresse salino. Revista Brasileira de Engenharia Agrícola e Ambiental, v.10, p.804-810, 2006. https://doi.org/10.1590/S141543662006000400004

Uexkull, H. R. Response of coconut to (potassium) chloride in the Philippines. Oléagineux, v.27, p.13-19, 1972.

Wuidart, W.; Lamothe, M. N. Germination des semences et développment des plants de cocotier en fonction de la position de la noix. Oléagineux, v.36, p.599-602, 1981.

Yemm, E. W.; Cocking, E. C. The determination of amino-acids with ninhydrin. Analyst, v.80, p.209-213, 1955. https://doi.org/10.1039/ an9558000209 